exchange between clay minerals and stain, and this can be evaluated quantitatively by placing the filtrate between a light source and a photo-electric cell having a sensitive galvanometer in circuit. Clay fractions which are dominantly quartzose in type remove little of the stain, while those of the kaolinite or beidellite types produce an almost clear filtrate. Colour differences in the filtrates obtained from different clay fractions can then be measured by means of the galvanometer.

The importance of the mineral content of soil mortars has already been demonstrated ${ }^{2}$, and the method outlined above offers a rapid means of detection of soil mortars rich in either kaolinite or beidellite clays. It is then only necessary to measure the relation between the volume of the soil mortar and its water content in order to distinguish between soil mortars with dominant kaolinite and those in which beidellite clays are the more abundant. In the former case the expansion is far less than in the latter on increase in moisture content.

It is very unusual to find any reference to the exact nature of the clay fraction present in gravels used for highway foundations when reference is made to the large American and other literature on this subject. Unless this fact is taken into account, serious foundation failures are likely to occur owing to the presence of dangerous clays having marked expansive properties, and it is clear from recent work in the Union of South Africa that the physical properties of the minerals forming the clay fraction are of dominant significance in determining the behaviour of such gravels under field conditions.

B. H. KNIGHT.

Civil Engineering Department,

University of the Witwatersrand,

Johannesburg. Nov. 11.

i Bosazza, V. I., Nature, 146, 334 (1940).

Knight, B. H., J. S, African Soc. Civ. Eng. (July 1940).

\section{Reservation of Scientific Workers}

The classification of scientific workers in the Schedule of Reserved Occupations results in an extremely inefficient use of scientific talent for the national cause, and is giving rise to much bewilderment and exasperation.

The list includes a few highly special classes, and a few very broad ones, with a variety of ages of reservation. The difficulty is that many classes overlap, and that most scientific workers can with equal propriety be included in several of them. An early example arose from the separate classification of university teachers and research workers in universities. Most science lecturers do some research, and many of them devote nearly all or even all their time to research. Chemists, physicists, histologists (not human), exist side by side with the class which can cover them all, namely, that of "research worker in a recognised institution". In practice, this last class includes those whose specialities are not separately listed, and those who fall midway between other listed categories. A physical chemist, being neither quite a chemist nor quite a physicist, would register in the general class, with the result that he is now reserved at thirty, instead of at twenty-one, as he would have been had he called himself a physicist.

The situation, which is certainly most worthy of contemplation, is that of a scientific worker being called up while his own laboratory assistant is left. This has already happened, and must soon be happen- ing on a large scale, for the laboratory assistant is reserved at twenty-five in his trade capacity and at twenty-one for general service, which has meant, in practice, that he is reserved at the lower age. Yet it usually takes the man of science as many weeks to train his assistant as he himself took years to be trained.

A most remarkable complete omission from the list is that of mathematician; if he applies his mathematics to physics he may be reserved as a physicist, but if his mathematics are sufficiently 'pure' to be applicable to all sciences, then he is not reserved at all. A biologist, who has specialized in genetics, may be of the greatest use to agricultural research, but he will be called up under thirty, because there are too few geneticists to make a separate category.

These anomalies have given rise to the curious practice of changing the description of the occupation on the Ministry of Labour Index, as ages of reserva. tion alter. A more rational procedure, and one which would give less work to the departments concerned, would be to make individual reservations on the basis of information filed at the Central Register. Since this information was recorded before the issue of the Schedule it would be unbiased by any consideration of reservation ages and, moreover, includes proper particulars of capacities to do work outside the present occupation.

W. L. Stevens.

The Galton Laboratory, A. C. Fabergé.

Rothamsted Experimental Station, Harpenden, Herts.

Dec. 9.

\section{Early Post-Glacial Conditions in England}

DR. L. HAwKEs's ${ }^{1}$ interesting letter raises wide issues, if (as we believe should be done) the more precise term 'early Post-Glacial' be substituted for 'Pleistocene'. That a tundra condition in Britain succeeded the disappearance of the Pleistocene icesheets now seems more than probable. Evidence for this is widespread. In the great sand-pit at Greenside, north Durham, one of us (W.A.) in 1936 noticed several 'sand-dykes' with funnel-shaped tops, which we agreed were due to frost cracking. Since then many other instances have been noted in north-east England, always in surface deposits, and usually, though not invariably, in gravels; and solufluxion phenomena are known on the Yorkshire coast, while other tundra phenomena abound in the north Lincolnshire gravels.

These data confirm Kilroe's ${ }^{2}$ admirable description and figure (made so long ago as 1908) of frost-cracks in some north Irish gravels, and recorded by him as proof of tundra conditions. Each and all are definitely Post-Glacial. They are therefore presumably contemporaneous with Nehring's tundra period of the north German Plain. May it not be that Reid's ${ }^{3}$ "thoroughly Arctic fauna and flora", so well known in the south of England, as seen in the Coombe Rock and other deposits, are of similar date ?

R. G. Carruthers.

W. ANDERSON.

Geological Survey of Great Britain, King's College,

Newcastle-on-Tyne, 2.

${ }^{1}$ Nature, $146560(1940)$.

"Mem. Geol. Sur. Ire., "Geology of Country around Londonderry", 62, 63 (1908).

${ }^{3}$ Quart. J. Geol. Soc., 48, 369 (1887). 